\title{
A Health GIS Based Approach to Portray the Influence of A mbient Temperature on G oat Health in Two Different Agro-Climatic Zones in West Bengal, India
}

\author{
Mihir Bhatta*, Debasish Das**, Probal Ranjan Ghosh***
}

\begin{abstract}
Thespatial and temporal distribution patterns of thelivestock heal th statusin the developing countries like India are complex. In this regards, the application of Geographical Information System (GIS) is valuableas it has many features that makeit an ideal tool for usein animal health surveillance, monitoring, prediction and its management strategy. Thegoal of the present study is to find out the effect of ambient temperatureon goat heal th in two different agro-climatic zones in West Bengal, India with theadditional help of GIS technology. The highest mean value of temperature $\left(42.6 \pm 1.5^{\circ} \mathrm{C}\right)$ has been reported during the month of A pril or May in theseason of pre-monsoon in Purulia. Survey of India (SOI) topographical sheets (73l/ 3and 79B/ 5) are used to map the study areas. Top sheets are scanned, geo-referenced and then digitized with thehelp of GIS software. The biochemical and meteorological data areentered to the newly prepared digitized map as thenon-spatial data or attributes. M oreover, thepresent work aims to confer an indication of the potential applications and usages of a GIS in the field of animal heal th for advancing the knowledge about this innovative approach of goat heath surveillance and monitoring.
\end{abstract}

Keyw ords: Goats; GIS; Pre-M onsoon; Post-M onsoon; Purulia; Nadia.

\section{Introduction}

Our earth is now undergoing through a rapid demographic and ecologic changes, including tremendous pressure of population growth with successive increasing problems of food insufficiency[1], Inadequate development in public health sector, climate changes and simultaneous loosing of biodiversity, and the impacts on ecosystems which in common affects human and animal health [2]. The most important reason for using a GISin an animal health information system is to facilitatethespatial component of animal health to beincluded in the reporting and analysis of animal health data. The applications of GIS can be divided into three main areas, which can be explained differently as inventory, analysis and management applications [3] or data visualisation, data exploration, and data modelling in an alternateway [4]. The problem is to consider whether a GIS for sustainably developing countries like India is able to providethefull range of functions required by such a system. A $n$ animal health information system has the necessary purposes of gathering, storing, analysing as well as reporting information on animal health [5]. Insertion of GIS into an animal health information system allows thespatial component of
A uthor's Affiliation: ***Department of Environmental Science, University of Kalyani, Kalyani, Nadia-741235, West Bengal, India. ***Department of Veterinary Physiology, West Bengal University of A nimal \& Fishery Sciences, 37 Khudiram Bose Sarani, Kolkata-700037, West Bengal, India.

Reprint's request: Debasish Das, Department of Environmental Science, University of Kalyani, Kalyani, Nadia-741235, West Bengal, India.

E-mail: ddas_kly@rediffmail.com

animal health to be incorporated into this process. Theefficiency of data collection system has no impact here, or how equipped the data storage method, excluding data analysis, and ultimately reporting of the animal health information, the system provides no useful function [6]. Now in thedeveloping country like India, GIS is becoming very popular in the observation as well as to track and to monitor the vector-borneand water-bornediseases [7].

\section{M ethodology}

Survey of India (SOI) topographical sheets of 1 : 50,000 scales ( No. $73 \mathrm{l} / 3$ and $79 \mathrm{~B} / 5$ ) are used to map the study areas. Topographical sheets are scanned, geo-referenced and then digitized with the 


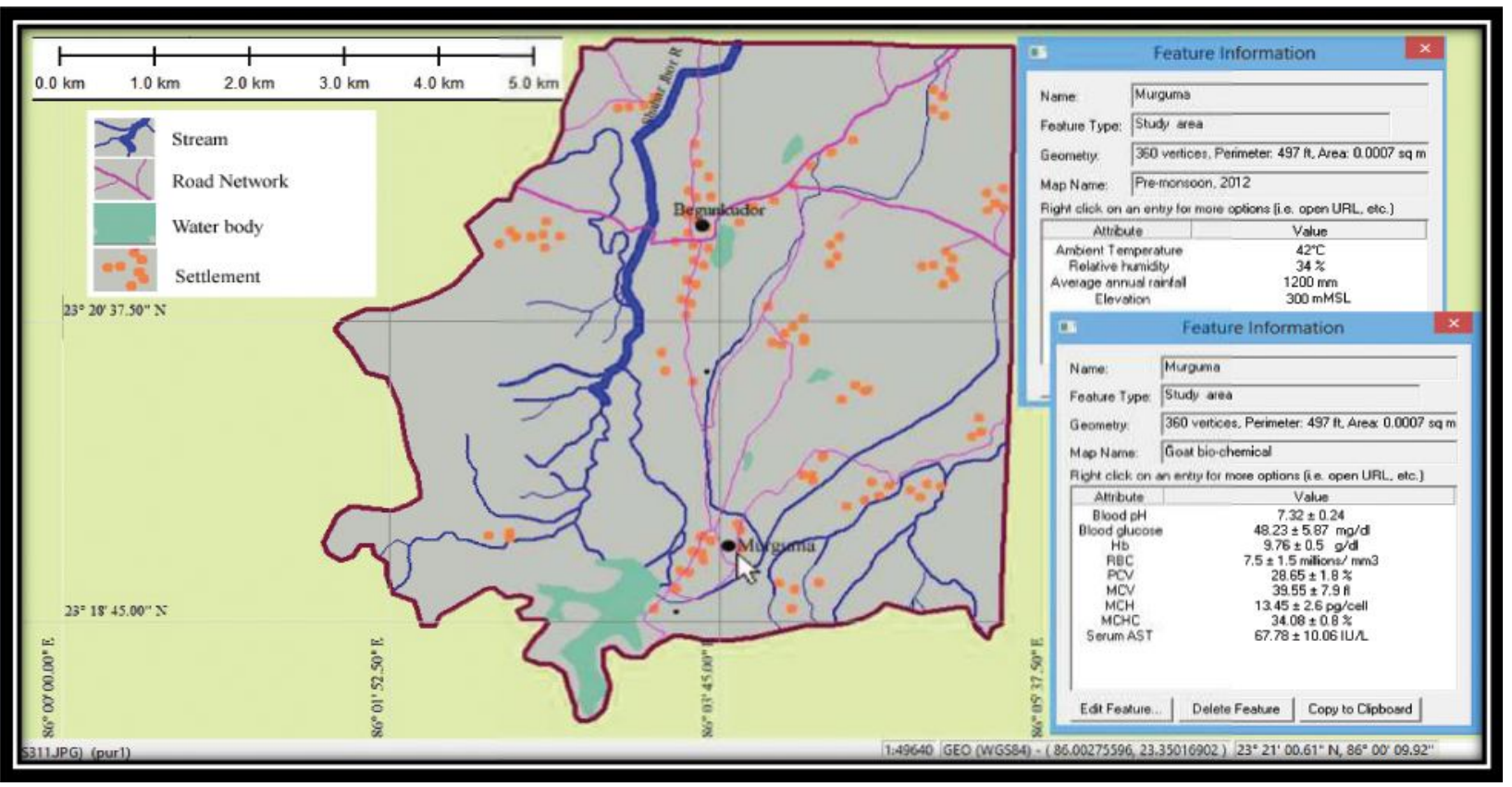

Fig. 1: Non-spatial attributes including biochemical parameters of the pre-monsoon in the study area of Purulia

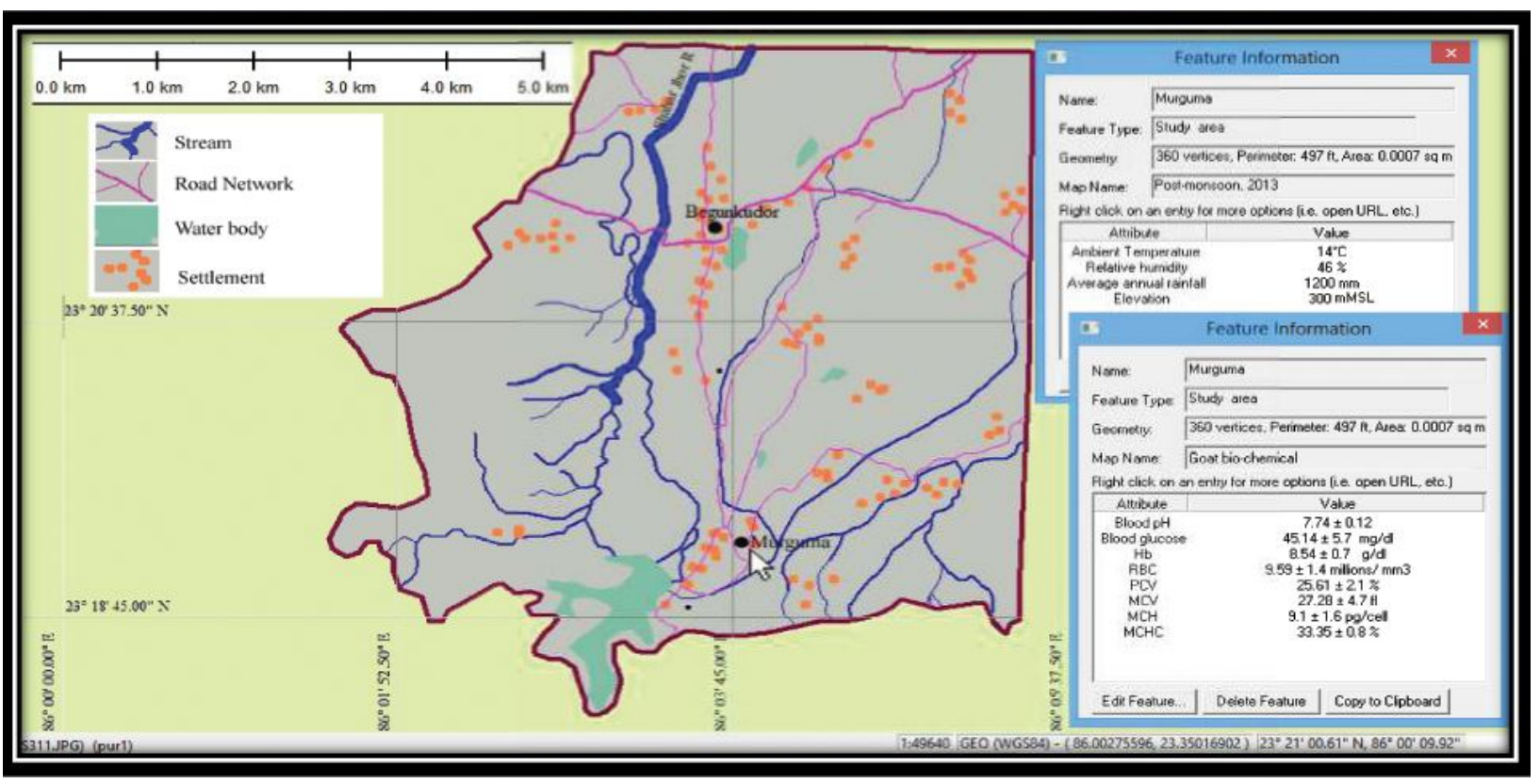

Fig. 2: Non-spatial attributes including goat's biochemical parameters of the post-monsoon in the study area of Purulia

help of GIS software [8] such as TNTmips ${ }^{\circledR}$ 7.2packages (@2015 Micro Images Inc.), Global Mapper $\circledast$ etc. The biochemical parameters such as blood glucose (mg/ dl), total RBC (millions/ mm3), total haemoglobin or $\mathrm{Hb}(\mathrm{g} / \mathrm{dl})$, packed cell volumeor PCV (\%), mean corpuscularvolumeor MCV (femtoliter per cell or $\mathrm{fl}$ ), mean corpuscular haemoglobin or $\mathrm{MCH}$ (in picogram per cell or pg) and mean corpuscular haemoglobin concentration or MCHC (\%) and meteorological datasuch asambienttemperature(ÚC), relative humidity (\%), average annual rain fall $(\mathrm{mm})$ and elevation (mMSL) from previously published article[9] and from some recent work of the same authors, has been entered to the newly prepared digitized map as thenon-spatial data or attributes. The data have been entered in such a manner so that, when themouse (computing) has been ported and clicked on any selected point subsequently opening one or more windows containing theinformation about different non-spatial attributes (Figure 1, 2, 3 and 4). Latitude and longitude of the different study sites have been measured using GPS (eTrex, Garmin International, Inc.). 


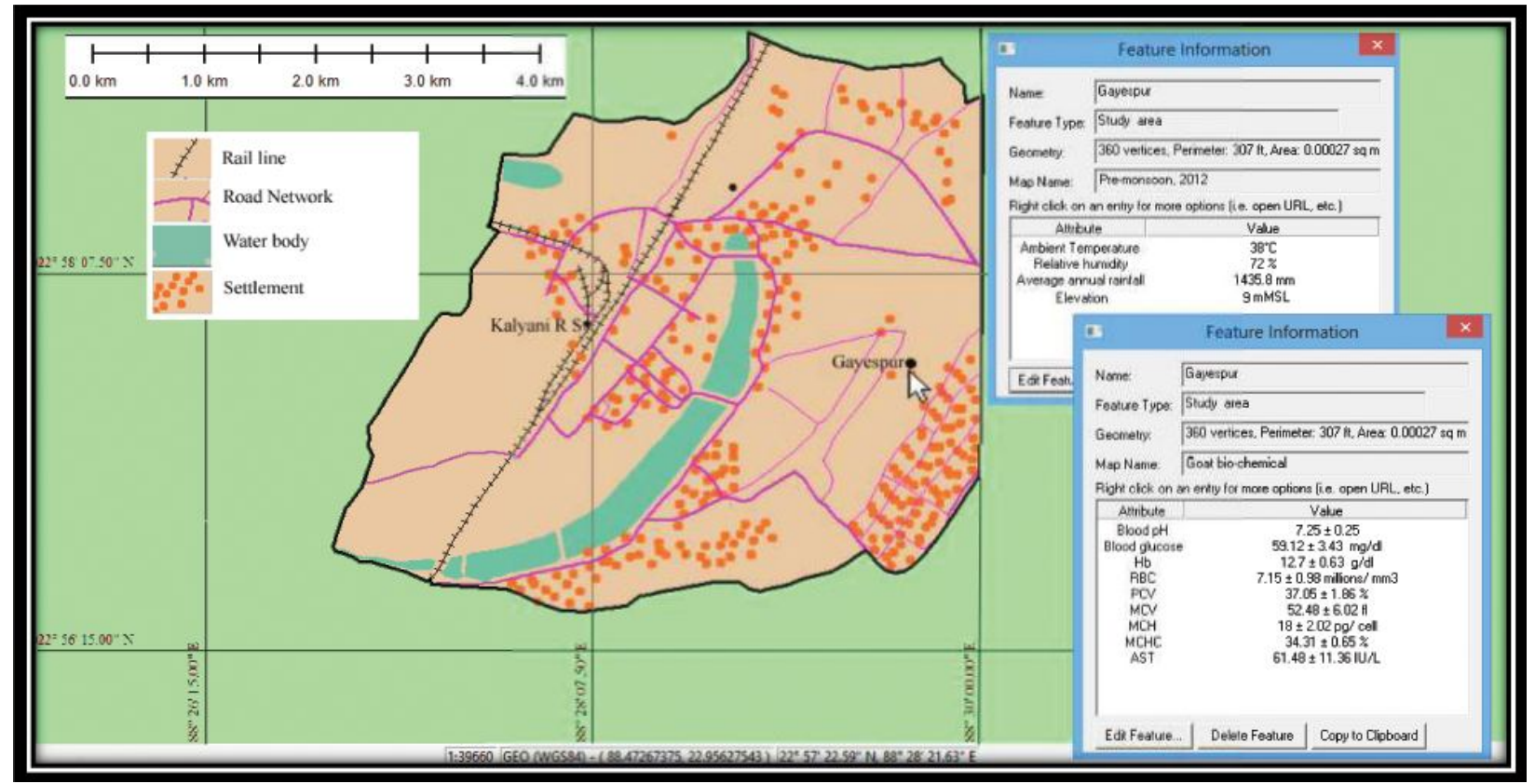

Fig. 3: Non-spatial attributes including goat's biochemical parameters of the pre-monsoon in the study area of Nadia

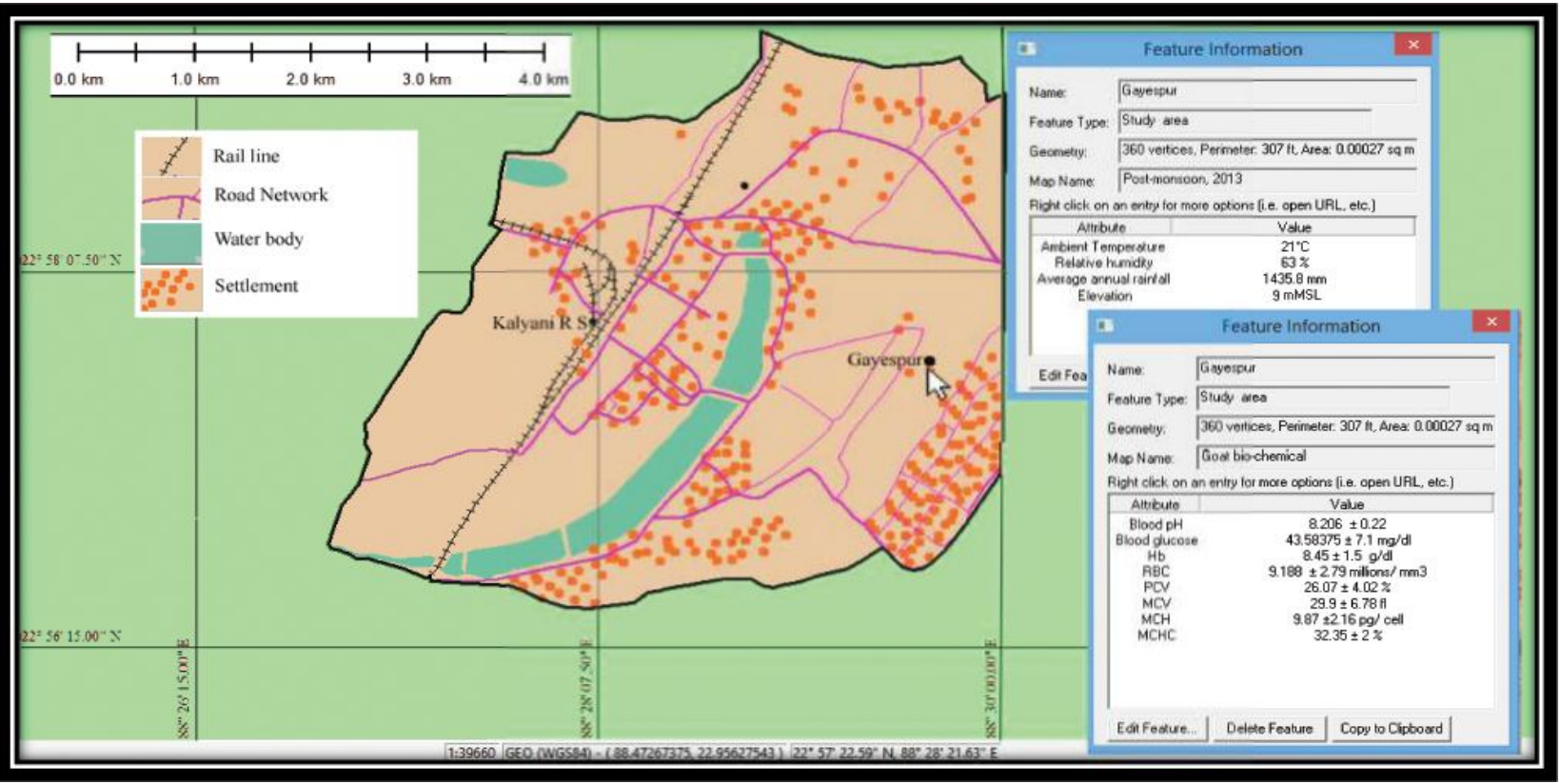

Fig. 4: Non-spatial attributes including goat's biochemical parameters of the post-monsoon in the study area of Nadia

\section{Results and Discussion}

The physiological, biochemical and meteorological data, from previously published article by the same authors [9] has been entered to the newly prepared digitized map as the non-spatial data or attributes. A n effectivelinking of geographical and attribute information is an essential part of the function of a GIS. As a result, most of the GIS have very potent, and simpleto use data linking capacities. This makes them well suited to thetask of integrating themany different data sources that arenecessary in an animal health information system. Keeping this view in mind the present work has been done. The maps are prepared from the topographical sheet 73 I/ 3, showing M urguma, Purulia and the maps are prepared from the topographical sheet $79 \mathrm{~B} / 5$, showing Gayespur, Nadia. Thenon-spatial attributes i.e. biochemical parameters of thegoat blood during 
the pre-monsoon season in thestudy area Murguma, Purulia have been entered in the map (Figure 1). Figure 2 showing the non-spatial attributes i.e. biochemical parameters of the goat blood during the post-monsoon season in the same study area of Purulia. Figure 3 and 4 showing non-spatial attributes i.e biochemical parameters of thegoat blood in the study area of Gayespur, Nadia, for the season of pre-monsoon and post-monsoon respectively.

The one of the present study are aMurguma, situated in Purulia district, which fall under Eastern Plateau and Hills (agro-climatic) region of India [10]. It receives about $1200 \mathrm{~mm}$ of rainfall annually. During premonsoon season theaverageambient temperaturehas been found $42^{\circ} \mathrm{C}$ and relative humidity has been found $34 \%$ (Figure1). Whereas during post-monsoon season theaverageambient temperatureand relativehumidity has been found $14^{\circ} \mathrm{C}$ and $46 \%$ respectively (Figure 2 ). Theother study area of thepresent w ork is Gayespur from Nadiadistrict, which fall under Lower Gangetic Plains (agro-climatic) region of India[11]. Hereannual rainfall ranging between $1200 \mathrm{~mm}$ to $1700 \mathrm{~mm}$. During premonsoon season the averageambient temperature has been found $38^{\circ} \mathrm{C}$ and relative humidity has been found $72 \%$ (Figure 3 ). Whereas during post-monsoon season the averageambient temperature and relative humidity has been found $21^{\circ} \mathrm{C}$ and $63 \%$ respectively (Figure 4).

Themaps of Figureland Figure2areclearly showing marked differences in biophysical and biochemical parameters between two seasons in Murguma, Purulia [12]. Similarly Figure 3 and Figure 4 show some differences biochemical parameters between two seasons in Gayespur, Nadia. Herewecan comparethe Figure 1 with Figure 3, i.e. comparing bio-chemical parameters of goatsunder study of premonsoon season between the two present study areas of Purulia and Nadia. Which show significant difference in many aspects [9].H owever, therearelesssignificant difference in between thetwostudy areasPurulia and Nadiaduring thepost-monsoon seasons (comparing Figure2and Figure 4). Someother importantfindingsfrom theprepared map are: blood $\mathrm{pH}$ valuesin pre-monsoon arelower than postmonsoon in both theregion i.e. Purulia and Nadia. The blood glucose level always has been higher in postmonsoon. $\mathrm{MCHC}$ values remain unchanged throughout theyear aswell as in two different agro-climaticregions. As many workers [13] reported the steady level of $\mathrm{MCHC}$ during different seasons.

We know that the purpose of an animal health information system is to giveinformation that provides abetter understanding of theepidemiology of disease and the continuous study of goat's bio-physical parameterssuch as rectal temperature, heart rate, pulse rate and bio-chemical parameters such as blood $\mathrm{pH}$, blood glucose, RBC, PCV, MCV, MCH, MCHC values can givean idea of thegoat heath in real time[14\&15]. Examination of thespatial component of animal health data yields another important advantage of GIS - the capability to quickly identify thedata errors. Lost and out-of-range data can be simply identified when the data going to incorporated into the map. Previously GIShavebeen effectively applied to a number of definite problems in veterinary epidemiology, such as calculating therisk of East Coast fever to thelivestock in A frica [16]. An effectivelinking of geographical and attributeinformation is an essential part of thefunction of aGIS. A saresult, most of theGIShavevery potent, and simple to use data linking capacities. This makes them well suited to the task of integrating the many different data sources that are required in an animal health information system [14].

\section{Conclusion}

GIShas been efficient in collection and presentation of spatial and non-spatial data as well as disease occurrences, which assist to prepare immediate remedial and preventive approaches for disease prevention and management [17]. It isobvious that the systems in most developing countries fall far short of theoptimal, dueto a range of constraints strangeto the developing parts of the world [18]. In the present context, the ability of GIS to link graphic and nongraphic data facilitates prevailing analysis of different non-spatial distribution and related issues. It will be feasibleand quite easy to draw themapsand visualize possible temporal and spatial risk factors [19]. Particular problems exist in thecollection of unbiased, reliable, timely information on the health status of livestock populations, and in the management of animal health data [20]. GIS provides strong spatial analytical potentialities [21], butthelimited availability of consistent animal health data, such as that collected by dynamicsurveillance, theanalysisis of limited value. Thesesystems are being increasingly applied to animal diseasecontrol asan integral component of supporting system concerning decisions in thefield of veterinary science. Thus, GIS can besighted as a possibletool for a novel move towards of science [22], to endorse the animal health in terms of monitoring, observation as well as disease management policies.

\section{Acknowledgement}

Theauthors aregrateful to the Higher Education Department, GOWB and University of Kalyani for funding and other necessary help. 


\section{References}

1. Pat JA, Campbell-LendrumD, Holloway T and Foley JA I Impact of regional climate change on human health. N ature. 2005; 438(7066): 310-317.

2. Mahima, Verma AK, Kumar A, Rahal A and Kumar $V$ Veterinarian for sustainable development of humanity. A sian J. A nim. V et. Adv. 2012; 7(5): 752-753.

3. Crain, I.K., and C.L. MacDonald. From land inventory to land management. Cartographica. 1984; 21, 40-46.

4. Bailey T C and Gatrell A C. Interactivespatial data analysis. Longman, Harlow, 1995; pp 20-23

5. Malone, J.B. and Zukowski, S.H. Geographic model sand control of cattleliver flukes in southern USA. Parasitology Today 1992; 8: 266 - 270.

6. Hendrickx G, Biesemans] and deDeken R. The use of GIS in veterinary parasitology. In P Durr, A Gatrell (eds.), GIS and spatial analysis in veterinary science, CABI Publishing, Wallingford. 2004; 145-176.

7. Pattnaik B, Venkataramanan R, Tosh C, Sanyal A, Hemadri D, Samuel AR, Knowles NJ and Kitching RP. Genetic heterogeneity of Indian field isolates of foot-and-mouth disease virus serotype $O$ as revealed by partial sequencing of $1 \mathrm{D}$ gene. Virus Res. 1998; 55(2): 115-127

8. Roy U. and Das D.Application of Spatial Technologies in Drought-hit Rural Land-use Planning, Thelnd. A gricults. 2014; 58(1): 49-56

9. Bhatta M, DasD, Ghosh PR. Theeffect of ambient temperature on some biochemical profiles of Black Bengal goats (Capra aegagrus hircus) in two different agro-climatic zones in West Bengal, India. IO SR J. P harma. Biol. Sci. 2014; 9 (4), 32-36

10. Pandey MM. Long-term Strategies and Programmes for Mechanization of A griculture in A gro Climatic Zone-VII: Eastern Plateau and Hills region, Department of Agriculture \& Cooperation, M inistry of Agriculture. Govt. India. 2006; pp. 144 - 168.

11. Sirohi NPS. Long-term Strategies and Programmes for Mechanization of A griculture in Agro Climatic Zone-III: Lower Gangetic Plains region, Department of A griculture \& Cooperation, M inistry of Agriculture. Govt. India. 2006; pp. 96 - 105.

12. Bhatta $M$, Das $D, G$ hosh PR. Seasonal variation in erythrocytic indices of Black Bengal goats
(Capra aegagrus hircus) in Purulia, West Bengal, Ind J A nimH elth. 2013; 52(1): 43-48.

13. Bhatta M., Das D. and Ghosh P.R.Theinfluence of ambient temperature on thyroid activity, erythrocytic indices and some biochemical parameters of Black Bengal goats (Capra aegagrus hircus), Ind. J. Biol. 2014;1(2): 53 - 58.

14. Coles EM. V etenary Clinical Pathology. $3^{\text {rd }}$ Ed., WB Saunders, Philadel phia; 1980.

15. Kaushish S, Bhattia DC, A rora KL. Studies on the adaptability of sheep to subtopical climate and seasonal changes in rectal temperature, cardio-respiratory and haematological attributes of N ali sheep. Ind V et J. 1976; 33: 760-765.

16. Lessard, P., L'Eplattenier, R., Norval, R.A.I., Perry, B.D., Dolan, T.T., Burrill, A., Croze, H., Sorensen, M., Grootenhuis, J.G., Irvin, A.D. The use of geographical information systems in estimating east coast fever risk to A frican livestock. P roceedings of the $V$ th International Symposium on $\checkmark$ eterinary Epidemiology \& Economics, 1988; pp 234-236.

17. DhamaK, VermaAK, Tiwari R, Chakraborty S, Vora K, Kapoor S, Deb R, Karthik K, Singh R, Munir M, Natesan S. A perspective on applications of geographical information system (GIS); an advanced tracking tool for disease surveillance and monitoring in veterinary epidemiology. A dv. A nim. V et. Sci, 2013; 1: 14- 24.

18. Moncayo, A.C., Edman, J.D. \& Finn, J.T. Application of geographic information technology indetermining risk of eastern equine encephalomyelitis virus transmission .J. A meri. M osquito Contr.A sso., 2000; 16: 28-35.

19. Hartemink $N$, VanwambekesO, Heesterbeek $\mathrm{H}$, Rogers D, Morley D, Pesson B, Davies C, MahamdallieSand Ready P. Integrated mapping of establishment risk for emerging vector-borne infections: a case study of canine Leishmaniasis in southwest France. P LoS O ne, 2011; 6(8): e20817.

20. Emmanuel NN, Loha N, Okolo MO and Ikenna Landscape epidemiology: An emerging perspective in the mapping and modelling of diseaseand diseaserisk factors. A sian Pac. J. Trop. D is. 2011; 1: 247-250.

21. Campbell J B. Introduction to RemoteSensing, $2^{\text {nd }}$ Ed. Guildford Press, New York; 1996.

22. Burrough PA and McDonnell RA. P rinciples of Geographical Information Systems, $1^{\text {st }}$ ed., Oxford University Press Inc., N ew York, 1998; 35-57. 


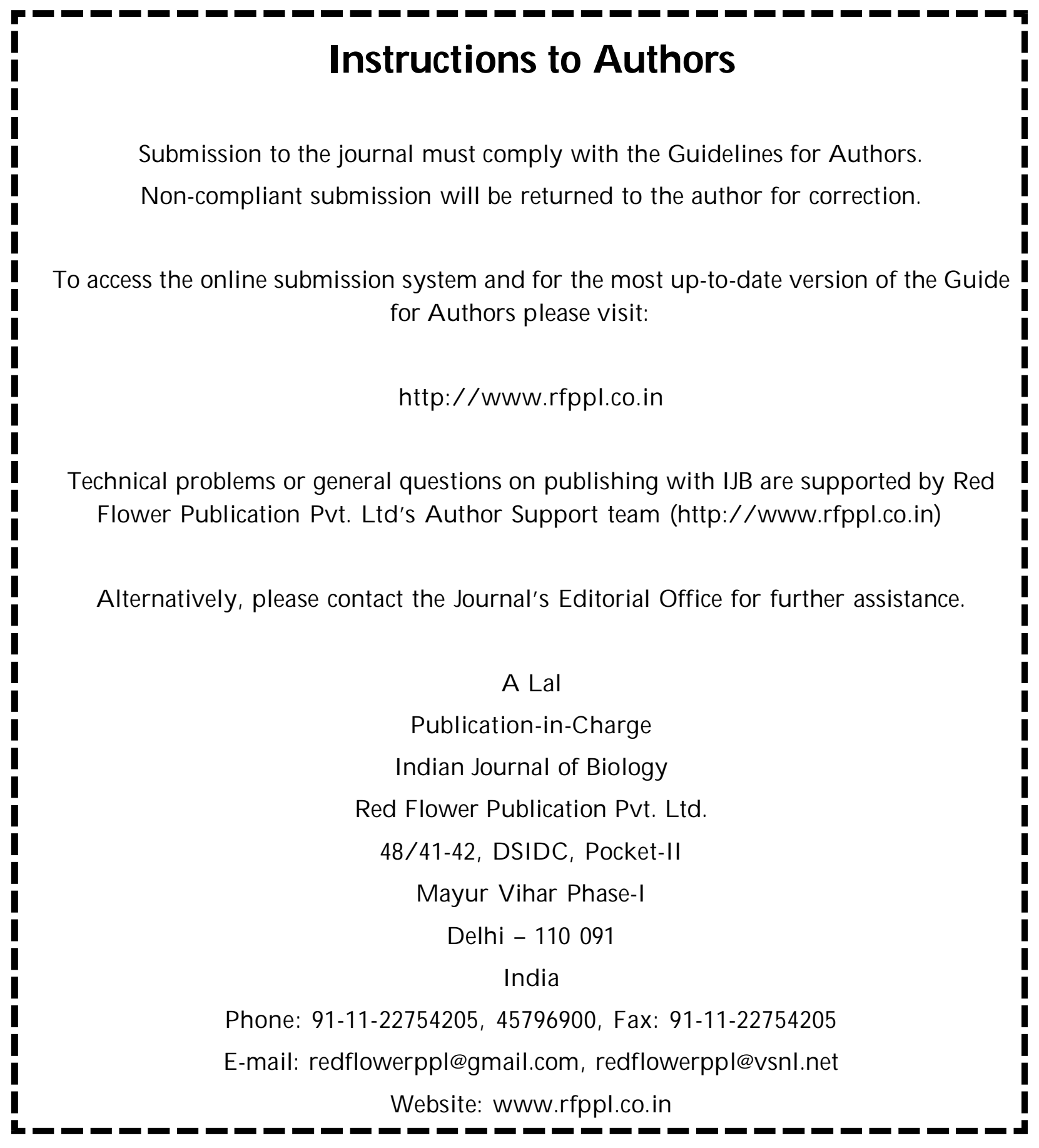

